\title{
REFINEMENT OF THE TSEBELIS' (1990) ECONOMIC SANCTION GAME
}

\author{
Khalifany Ash Shidiqi \\ Faculty of Economics and Business, Universitas Muhammadiyah Yogyakarta, Indonesia \\ Jalan Lingkar Selatan, Bantul, Yogyakarta 55183 Indonesia, Phone +62-274-387656 \\ Correspondence E-mail: khalifany.ash@fe.umy.ac.id
}

Received: December 2015; Accepted: March 2016

\begin{abstract}
Economic sanction has been widely used and increasingly a popular tool in maintaining peace and political stability in the world. The use of economic sanction, as opposed to the use of military power, to punish target countries have been supported by the Charter of United Nations (UN). Tsebelis (1990) modelled economic sanctions using game theory namely the Sanction Game. This paper focuses on the refinement of the sanction game proposed by Tsebelis (1990) to analyse international relations. Recent findings from various studies on the effectiveness of economic sanction have been used to reconstruct the game.

Keywords: Economic Sanction, the Sanction/Inspection Games, Mixed Strategy Equilibrium.
\end{abstract}

JEL Classification: C79, K42, F51

Abstrak: Sanksi ekonomi telah banyak digunakan sebagai alat yang populer untuk mengelola kedamaian dan stabilitas politik internasional. Penggunaan sanksi ekonomi didukung oleh piagam PBB untuk menghukum suatu negara yang membahayakan perdamaian internasional. Pertama kali dilakukan oleh Tsebelis (1990) dalam memodelkan sanksi ekonomi dengan menggunakan teori permainan. Model yang dikonsturksi oleh Tsebelis (1990) dinamakan "The Sanction Game". Studi ini focus pada perbaikan "The Sanction Game" yang sebelumnya telah dibangun oleh Tsebelis (1990). Studi ini menggunakan temuan-temuan dari berbagai macam studi untuk memperbaiki "The Sanction Game" sehingga permainan yang dijalankan lebih mendekati realitas.

Keywords: Sanksi Ekonomi, the Sanction/Inspection Games, Mixed Strategy Equilibrium. Klasifikasi JEL: C79, K42, F51 


\section{INTRODUCTION}

Economic sanction has been used as a primary tool by the United Nations in order to maintain peace and political stability in the world. The use of economic sanction has been supported by the Charter of United Nations (UN). Any action with respect to threats to the peace will be dealt by the Security Council of United Nations (SCUN) without involving the use of armed forces. ${ }^{1}$ The economic sanction may be perceived as an alternative policy to military approach (Baldwin, 2000). Furthermore, the economic sanction has been considered to be more efficient in comparison to a military action in dealing with various violations, breaches, and aggressions (Hufbauer, et. al., 2007:5).

In modern era, the use of economic sanction has increased significantly, however the effectiveness of the policy may be questionable. This phenomenon has been debated for many years among scholars (see O'Connor (1940), Sunderland (1960), Tsebelis (1990), Pape (1997), and Hufbauer et.al. (2007), among others). Tsebelis (1990) argued that from 86 cases of economic sanction, only 33 cases were considered effective. Hufbauer, et. al. (2007) reported that from year 1914 to 2006 there were 174 economic sanction cases and only about 34 percent of those were considered effective.

Modelling of economic sanction may be conducted by using either decision theory or game theory. Tsebelis (1990) argued that economic sanctions is better being analysed using game theory on the ground that the probabilities of success and failure in committing a violation are affecte $\mathrm{d}$ by the interactions of rational players. Indeed a country is not a human, however, any decision to violate/follow international law/agreement by a country have been made by rational players which can be modelled as a representative agent.

This paper aims to refine the sanction game proposed by Tsebelis (1990). The concept of the sanction game proposed by Tsebelis (1990) is discussed in research methods.. The refinement

United Nations, Charter of the United Nations, Chapter VII, Article 41 of the sanction game is presented in result and discussion. Recent findings from various studies will be used to reconstruct the game especially in determining the payoffs.

\section{RESEARCH METHOD}

This paper uses analytical approach to construct economic sanction phenomenon into a game theoretical analysis. The sanction game proposed by Tsebelis (1990) does not have pure strategy Nash equilibrium. Hence, the analysis in finding mixed strategy Nash equilibrium is by using minimax method.

\section{The Sanction Game}

The method used in this study is the approach of Error Correction Model (ECM), because this model is able to test whether the empirical model is consistent with economic theory and in the solution of the time series variables are not stationary and spurious regression (Thomas, 1997). Spurious regression is chaotic regression, with a significant result regression of the data that is not related.

Tsebelis (1990) modelled the interaction among countries in imposing economic sanction as a $2 \times 2$ game played simultaneously by representative agents and the game is called the sanction game. The row player represents target country, while the column player represents sender country. The target country may choose one of the two strategies available, namely to violate or not to violate international agreements/laws. ${ }^{2}$ On the other hands, the sender country may also choose one of the two strategies namely to impose sanction or not to impose sanction. The sanction game is presented in a normal form game as follows: (see Figure 1)

The sanction game does not have pure strategy Nash Equilibrium, implying that there is no player who chooses a particular strategy with probability equal to 1 . Nevertheless, the game has mixed strategy equilibrium. Suppose the target country chooses to violate with probability $x$ and the sender country chooses to

2 The agreements may be applicable for two countries (bilateral) or more than two countries (multilateral). 
enforce with probability $y$, then the mixed strategy equilibrium of the game is as follows:

$$
\begin{aligned}
& x^{*}=\frac{d_{2}-c_{2}}{a_{2}-b_{2}-c_{2}+d_{2}} \\
& y^{*}=\frac{d_{1}-b_{1}}{a_{1}-b_{1}-c_{1}+d_{1}}
\end{aligned}
$$

Indeed, Tsebelis' (1990) pioneer approach in adopting game theoretical approach to analyze international sanction should be acknowledged and appreciated. Nevertheless there are several caveats which can be noted in Tsebelis' (1990) model. First, the outcome (not violate, sanction) may not be realistic in real world. Given the target country choose 'not to violate', would it be any impact on the target country whether or not the sender country chooses either 'sanction' or 'not to sanction'? In fact, the sender country does not have any justification to sanction the target country since the target country chooses 'not to violate'.

Second, Tsebelis (1990) modelled the phenomena in international relation by using the sanction game with aggregated payoffs. Each cell of the payoff matrix reflects the net benefits which have been arisen from the combination of two strategies chosen by two players simultaneously. The use of aggregated payoffs does not permit us to trace the elements of benefits and costs which formulate the net benefits in each cell of the payoff matrix. Consequently, as long as the aggregated payoffs have been used in the model, any attempt to change either the severity of the sanction or the incentive for not to violate the law, the impact of the policy to the process of the change in the elements of benefits and costs is not observable. This may raise a further inquiry on how realistic Tsebelis' (1990) sanction game can be to represent phenomena of economic sanction in the real world.

\section{RESULT AND DISCUSSION}

\section{A Refinement of the Sanction Game}

The revised version of the sanction game is a 2x2 game played simultaneously by representative agents, namely the target and the sender countries. It is assumed that the target country is one or more countries which run missions that have tendencies to give a potential threat to the peace of the world. ${ }^{3}$ In this case, the missions have been perceived as a violation of international agreement/law or against the principles of the UN (see Charter of the UN, Chapter 1, article 1). On the other hands, the sender country is assumed to be a country or international authority (such as SCUN) as the main proposer in the use of economic sanction.

Hufbauer, et. al. (2007:44) argued that the economic sanction tend to be enforced gradually by the sender country. There are several activities which can be pursued by the sender country prior to the implementation of the sanction are: a) investigating the target country's activities, b) reporting the outcome of the investigation to the $\mathrm{UN}$, and c) sanctioning the target country approved by the UN if the target country's activities are proven to be a violation of international agreement/law. ${ }^{4}$

Pradiptyo (2007) refined the inspection game proposed by Tsebelis (1989) in modelling the deterrence effect in criminal justice system by using disaggregated payoffs. In the same manner, in this article, the sanction game modelled by Tsebelis (1990) is going to be reconstructed by using disaggregated payoffs. Empirical findings from several studies will be used to develop the disaggregated payoffs of the game.

From the target country's perspective, the violation of international agreement/law that has been carried out is justified as long as it gives rise to benefits obtained due to the conduct $\left(B_{v}\right)$. In this circumstance, the target country may be able to defend and to keep the mission running from any pressures. Given the target country chose to violate international agreement/law, if the sender country choose 'enforce', the target country is going to receive economic sanction $\left(C_{v}\right)$ and this will be

3 There are many cases, however, that this assumption may not necesarily hold, in the sense that the sender country may simply implement economic sanctions to any country which does not comply with the sender country interests.

4 Ibid, Chapter 7, Article 41 


\begin{tabular}{cccc} 
& & Enforce & Not Enforce \\
\cline { 2 - 4 } Target & Violate & $B_{v}-C_{v}$ \\
$B_{s}-C_{e}-C_{c}$ & $B_{v}+B_{r}, 0$ \\
\cline { 2 - 4 } & Country & $B_{r}, R_{b}-C_{e}$ & $B_{r}, R_{b}$ \\
\hline
\end{tabular}

Figure 2. The Revised of the Sanction Game

Where:

$\boldsymbol{B}_{v}$ : the target country's utility arises from committing a violation of international agreement/ law.

$C_{v}$ : the target country's disutility of receiving direct punishment (e.g. banned from international trade activities).

$\boldsymbol{B}_{r}$ : positive reputational effects to the target country for not being sanctioned.

$\boldsymbol{B}_{s}$ : the sender country's utility due to the success of the enforcement (indicated by sender's ability in detecting the violations and other positive effects for international society).

$\boldsymbol{R}_{b}$ : reputational benefits which have been arisen due to enforcing international agreement/law.

$C_{e}$ : direct costs of enforcement bourned by the sender country (e.g. costs of investigation).

$C_{c}$ : indirect costs bourned by the sender country in imposing economic sanction (e.g. the loss of potential international trade profit).

perceived as disutility by the target country. (see Figure 2)

Another utility will be obtained by the target country is reputational benefits $\left(B_{r}\right)$ which arise if the country has never been sanctioned. The target country may violate the agreements/laws, however, as long as the sender country has not observed the behaviour or the sender country does not mind with it, and then the sender country may not necessarily decide to impose sanction. In this case, the target country will have many accesses in the core of economic cooperation, international political relationship, and the trust that has been given by international society. In contrast, the target country which ever been or being sanctioned will only have limited access in the respective international activities. ${ }^{5}$

The utility $\left(B_{s}\right)$ will be obtained by the sender country when the enforcement process was successful. The utility has been indicated by the sender country's abilities in detecting, preventing, and solving any dangerous

5 US Government Interagency, International Crime Threat Assessment, Chapter 2. activities that give threat either to its sovereignty or the peace and political stability of the world. Those abilities give positive effects such as; (1) the security for many countries from the undesirable occurrence that might happen as the consequences from the target country's violation of the agreement/law, (2) the target country will get obstruction, so that it would be harder to violate, and (3) from the historical enforcement that have already been successful, the target country will think many times to repeat its unacceptable conduct, because the probability to be detected again is higher than previously.

Another utility will be obtained by the sender county is a positive reputational benefit $\left(R_{b}\right)$ as they have been able to retain their sovereignty or to uphold the peace for the world as stated by the UN. In this case, the reputational benefit will only be obtained by the sender country, if the target country has not done any violations (or when the sender country chooses payoff $c_{2}$ or $d_{2}$ and when target choose $c_{1}$ or $d_{1}$ ). Although, this reputational benefit will not be obtained when the target 
country chooses to violate and the sender country chooses not to enforce (or when the target country chooses payoff $b_{1}$ and the sender country chooses $b_{2}$ ).

It should be noted that any attempt to enforce economic sanction is costly, which obviously is being bourned by the sender country. It is assumed that the costs of enforcement consist of two elements, namely direct cost $\left(C_{e}\right)$ and indirect cost $\left(C_{c}\right)$ of enforcement. The direct costs of enforcement will be bourned by the sender country soon after economic sanction has been implemented, for instance the investigation costs, the costs in imposing the economic sanction, etc. Hufbauer et. al (2007:108) argued that one of the biggest costs in conducting enforcement is investigation costs.

The indirect costs of enforcement $\left(C_{c}\right)$ will be bourned by the sender country as its potential gains from trade and also gains from international relation decrease as the sanction is imposed. Hufbauer et. al. (2007:109) argued that one of the worst things that might happen from imposing economic sanction is the loss of potential profit that should be earned by both sides if the sanctions would have not been imposed. It is assumed in the model that prior to the imposition of the sanctions; the relationship between the sender and the target countries was good, especially in the core of economic cooperation. After imposing the economic sanctions their relationship was obstructed and perhaps there is a possibility that the good relationship will be vanished.

Consider $q$ be the probability of the sender country to enforce the economic sanction. If the expected outcomes to violate exceed the expected outcomes to comply, therefore the best response for target is as follows:

$$
\left(B_{v}-C_{v}\right) q+\left(B_{v}+B_{r}\right)(1-q) \geq B_{r} q+B_{r}(1-q)
$$

$B_{v} \geq q\left(C_{v}+B_{r}\right)$

The same thing happens to the sender, whether they want to enforce or not. Consider $p$ be the probability that the target will violate.
The best response will be obtained as follows:

$\left(B_{s}-C_{e}-C_{c}\right) p+\left(R_{b}-C_{e}\right)(1-p) \geq 0 p+R_{b}(1-p)$

$B_{s} p \geq C_{e}+C_{c} p$

Propotition 1: The target country is going to violate if the utility to conduct such activity dominates the expected disutility of serving direct punishment (economic sanction) and the expected loss of reputational

$\left[B_{v} \geq q\left(C_{v}+B_{r}\right)\right]$

Proposition 2: The sender country is going to enforce if the expected benefits of enforcement dominates the expected costs which may incurred due to enforcement

$\left[B_{s} p \geq\left(C_{e}+C_{c} p\right)\right]$

Similar to Tsebelis' (1990) model, the game above does not have pure strategy nash equilibrium. Therefore the mixed strategy equilibrium is presented as follows:

$p^{*}=\frac{C_{e}}{B_{S}-C_{c}}$

and

$q^{*}=\frac{B_{v}}{C_{v}-B_{r}}$

Equation (1), $p^{*}$ represent the probability of target country to violate. Equation (2), on the other hand, $\mathrm{q}^{*}$ represent the probability of sender country to enforce.

Proposition 3: In equilibrium, given the level of punishment (i.e. $C_{e}$ ), the probability to violate is positively correlated to sender country's direct costs of enforcement $\left(C_{e}\right)$, but it is the reverse it's net benefit $\left(B_{s}-C_{c}\right)$. 
Proposition 4: In equilibrium, the probability to enfroce is positively correlated to target's utility to violate $\left(B_{v}\right)$, but it is the reverse of the target's miseries in serving economic sanction $\left(C_{v}+B_{r}\right)$.

\section{CONCLUSION}

Tsebelis' (1990) model was the first game theoretical approach in analyzing economic sanction. However, there are two defective elements that made the sanction game does not properly operate in accordance to the reality. First, the outcome (not violate, sanction) may not be realistic in real world. Given the target country choose 'not to violate', would it be any impact on the target country whether or not the sender country chooses either 'sanction' or 'not to sanction'? In fact, the sender country does not have any justification to sanction the target country since the target country chooses 'not to violate'. Second, Tsebelis (1990) modelled the phenomena in international relation by using the sanction game with aggregated payoffs. Each cell of the payoff matrix reflects the net benefits which have been arisen from the combination of two strategies chosen by two players simultaneously. The use of aggregated payoffs does not permit us to trace the elements of benefits and costs which formulate the net benefits in each cell of the payoff matrix. Consequently, as long as the aggregated payoffs have been used in the model, any attempt to change either the severity of the sanction or the incentive for not to violate the law, the impact of the policy to the process of the change in the elements of benefits and costs is not observable. This may raise a further inquiry on how realistic Tsebelis' (1990) sanction game can be to represent phenomena of economic sanction in the real world.

This refinement of the sanction game gives more realistic interaction between sender and target country, by changing the name of the strategy for sender country into enforce or not to enforce. It also uses disaggregated payoffs that permit us to trace the elements of benefits and costs which formulate the net benefits in making an action. In equilibrium, the probability to violate is positively correlated to sender country's direct costs of enforcement, but it is the reverse it's net benefit. In the other hand, the probability to enforce is positively correlated to target's utility to violate, but it is the reverse of the target's miseries in serving economic sanction.

\section{REFERENCES}

Baldwin, David A. (2000). The Sanction Debate and the Logic of Choice. The MIT Press, Vol. 24, No. 3: 80-107

Frey, B.S. and Holler, M.J. (1998). Tax Compliance Policy Reconsidered, Homo Oeconomicus 15:27-44.

Holler, M.J. and Host, V. (1990). Maximin vs Nash Equilibrium: Theoretical Results and Empirical Evidence, in Quandt R.E., and Triska, D. (eds). (1990), Optimal Decisions in Markets and Planned Economies. Westview Press.

Hufbauer, Gary Clyde, Jeffrey J. Schott, Kimberly Ann Elliott, and Barbara Oegg (2007). Economic Sanctions Reconsidered, Institute for International Economics. Washington DC, $3^{\text {rd }}$ Edition. ISBN 978-088132-408-2, 350pp.

O'conor, Theresa M (1940). The Embargo on the Export Provisions. Irish Historical Studies Publication. Vol. 5

Pape Robert A (1997). Why Economic Sanctions Do Not Work. The MIT Press, Vol. 22, No. 2 ,

Pradiptyo, R. (2007), Does Punishment Matter? A Refinement of the Inspection Game, Review of Law and Economics, vol. 3, issue 2, article 2, p.197-219.

Pradiptyo, R. (2009), The Impact of Sanctions and Crime Prevention Initiatives when Decisions are Strategic, Mimeo, Faculty of Economics and Business, Universitas Gadjah Mada.

Tsebelis, George (1989). The Abuse of Probability in Political Analysis: The Robinson Crusoe Fallacy. The American Political Science Review, Vol. 83, No.1.

Tsebelis, George (1990). Are Sanctions Effective? A Game-Theoretic Analysis, Journal of Conflic Resolution 34:3-28. 
United Nations. Charter of the United Nation Chapter V: The Security Council.

United Nations. Charter of the United Nations Chapter VII: Action with Respect to Threats to the Peace, Breaches of the Peace and Acts of Agression.

Sunderland, Riley (1960). The Secret Embargo. University California Press. Vol. 29. No. 1. 